\title{
Can Powdered Microencapsulated Whole Egg, Ulva lactuca and Grasshopper Improve Growth Performance and Economic Viability of African Catfish (Clarias gariepinus) Fry?
}

\author{
Abba Salisu ${ }^{1, *} \mathbb{B}$, Muhammad Al-Zibdah², Tariq Hasan Al-Najjar ${ }^{2}$ \\ ${ }^{1}$ Bayero University, Kano, Nigeria. \\ ${ }^{2}$ University of Jordan, Aqaba, Jordan.
}

\section{Article History}

Received 23 April 2019

Accepted 07 November 2019

First Online 07 November 2019

\section{Corresponding Author}

Tel.: +2347036319324

E-mail: asalisu.bio@buk.edu.ng

\section{Keywords}

Ulva lactuca

Grasshopper

Microencapsulated whole egg

C. gariepinus

\begin{abstract}
Clarias gariepinus fry requires feed that is rich in protein and essential fatty acid, but protein-rich feed is quite expensive especially when derived from animal origin. The present study aims to find less expensive feed for fry affordable for $C$. gariepinus farmers. About 3600 fries (Weight $=1.49 \pm 0.03 \mathrm{mg}$ ) produced artificially, were stocked in twenty-four plastic containers (measuring $30 \times 35 \times 24 \mathrm{~cm}$ ). The containers were divided into eight treatments $\left(T_{0}\right.$ to $\left.T_{7}\right)$ in triplicate. Seven different powdered feeds $F_{1}$ to $F_{7}$ (prepared from Ulva lactuca, Grasshopper and chicken egg) were respectively fed to the fry in the seven treatments $T_{1}$ to $T_{7}$ against Artemia Shell free as a control $\left(T_{0}\right)$ for two weeks. The results obtained revealed significant differences in terms of growth and economic response among the experimental treatments $(P<0.05)$. The finding shows reduction in feeding costs from $54.90 \%$ in control to $19.98 \%$ and $19.90 \%$ while maintaining high growth performance and net profit in $\mathrm{T}_{6}$ (1:1 mixture of grasshopper and microencapsulated whole egg) and $T_{5}$ (1:1 mixture of $U$. lactuca and Microencapsulated whole egg) respectively. Thus, for affordable feed and best profit, more should be explored on the benefit of using ingredients in $T_{5}$ and $T_{6}$ as possible feed for C. gariepinus.
\end{abstract}

\section{Introduction}

The main objective of any hatchery is to produce sufficient numbers of high-quality seeds, ranging from fry and fingerlings from available broodstocks (Marimuthu and Hanifa, 2009). One of the most important parts in fish hatchery is fry rearing or care, which involves the provision of the right quality feed at the right time. Failure to do that will result in high fry mortality, as the fry will have no food reserves of their own once the yolk sac has been absorbed (Gietma, 2003). Like many fish, C. gariepinus fry requires live feed and protein-rich diets like Artemia at the onset of exogenous feeding (Rumesy, 1980; Ovie and Ovie, 2002; Ibrahim, et al., 2008). However, preparation of live feed is associated with harmful microorganisms while the protein-rich feed is quite expensive, especially if the protein is of animal origin (Rumesy 1980). Artemia naupuli is reported to be deficient in some essential fatty acid (Olurin et al., 2014) and lack of essential fatty acids reduces growth and nutrient utilization of fish (Parker, 2012). Despite several studies to replace Artemia with different dry powdered feed, there still exists a high cost. Therefore, there is a need to investigate the alternative feed source for the progress of $C$. gariepinus production that will be produced at very low price, affordable for small-scale farmers.

Microencapsulated Whole egg is cheap and contains balance nutrients needed during the first ten days of life of most species of fish. However, watersoluble vitamins (especially ascorbic acid) and calcium are not sufficient in the "whole egg" and therefore 
needs to be supplemented (Chow, 1980). Also, microencapsulated whole eggs appear in the form of liquid that needs to be prepared every day or stored in the refrigerator to avoid deterioration. Hence, developing the dry powdered microencapsulated whole egg, together with some ingredients like Ulva lactuca and grasshopper, that are rich in vitamins and minerals to supplement their absence in the "microencapsulated whole egg" is necessary.

Ulva lactuca consist of Protein (9.91 - 27.9\%), Lipid (0.11-15.75\%), Ash (0.11-39.1\%), rich vitamins (e.g. Ascorbic acid) and minerals (e.g. Calcium, Iron) (Ortiz et al., 2006; Garci-Casel et al., 2007; Ergun, 2008; El Tawil, 2010; Mustafa and Saeed, 2014). U. lactuca has all the essential amino acids which constitute $5 \%$ out of the $12 \%$ of the total amino acids (Kumar and Khaldar, 2007) and essential fatty acid (Rohani-Ghadikolaei et al., 2012). Grasshopper is rich in nutrients (Blasques et al., 2012) especially minerals, fat (Sani, et al., 2014) with abundant essential fatty acid (Adeyeye, 2011), and essential amino acid of $351 \mathrm{mg} / \mathrm{g}$ crude protein (Adeyeye, 2005). Grasshopper could partially or completely be a substitute for conventional protein source in animal feed (Ojewola and Udom, 2005).

\section{Material and Method}

\section{Study Site and Source of Fish Seed}

The experiment was conducted at the Aquaculture unit of Marine Science Station, located in the south beach Gulf of Aqaba. Fry of $C$. gariepinus was produced artificially by inducing the fish (Female $=W t 0.7 \mathrm{~kg}$, Male $=1 \mathrm{Kg}$ ) through hormone treatment followed by artificial fertilization and incubation of fertilized eggs (De Graaf and Janssen, 1996). Approximately $56 \mathrm{gm}$ of eggs (equivalent to 41,941 egg pieces by considering $1 \mathrm{gm}$ of eggs to contain 750 eggs) were obtained from female brooder.

\section{Ingredients Collection and Preparation}

Roasted grasshoppers were purchased from the local market of Nigeria. The Grasshoppers were ground in a mortar and sieved in $300 \mu \mathrm{m}$ mesh and the powdered grasshoppers were collected.

The table eggs were purchased and "Microencapsulated whole egg" was prepared by beating the egg until the yolk and the white were homogenized. Boiled water $(150 \mathrm{ml} / \mathrm{egg})$ was poured over the eggs while stirring constantly (Chow 1980). The powdered microencapsulated whole egg was produced through freezed-drying followed by gentle oven drying at $40^{\circ} \mathrm{C}$ for two days. Dried Microencapsulated whole egg was then ground and sieved to pass through $300 \mu \mathrm{m}$ mesh thereby collecting the powdered egg.

Macroalgae (Ulva lactuca) were collected from the intertidal zone in front of the Marine Science Station Gulf of Aqaba. The collected Ulva lactuca were washed with freshwater to remove the salts and associated matters then dried at room temperature. Dried Ulva lactuca was ground and passed through $300 \mu \mathrm{m}$ mesh in powdered form (Figure 1).

\section{Proximate Analysis of the Tested Ingredient}

Proximate compositions of the experimental ingredients were analyzed following the standard method of the Association of the Official Analytical Chemist (AOAC 1990) (Table 3).

\section{Experimental Design}

About 3600 fries of 4 days old of almost equal size (weight and length of $1.49 \mathrm{mg}$ and $6.56 \mathrm{~mm}$, respectively) were stocked in 24 plastic baskets (measuring $35 \mathrm{~cm}$ in diameter and $24 \mathrm{~cm}$ height wrapped with fine cloth mesh). Baskets were divided into eight experimental treatments: $T_{1}, T_{2}, T_{3}, T_{4}, T_{5}, T_{6}$, $T_{7}$ and $T_{0}$ each in triplicate and suspended on eight tanks with constantan circulation of water (Fig.2). Seven different powdered feed (namely: $F_{1}=$ Ulva lactuca; $F_{2}=$ Grasshopper; $F_{3}=$ "Micro-encapsulating" whole egg; $F_{4}=$ $F_{1}+F_{2} ; F_{5}=F_{1}+F_{3} ; F_{6}=F_{2}+F_{3} ;$ and $F_{7}=F_{1}+F_{2}+F_{3}$ ) were prepared and fed the fry to the satiation in the respective experimental treatments against $T_{0}$ fed with Artemia $(0.5 \mathrm{~mm})$ as control. The mixed feed was prepared in an equal proportion of 1:1. The stage of
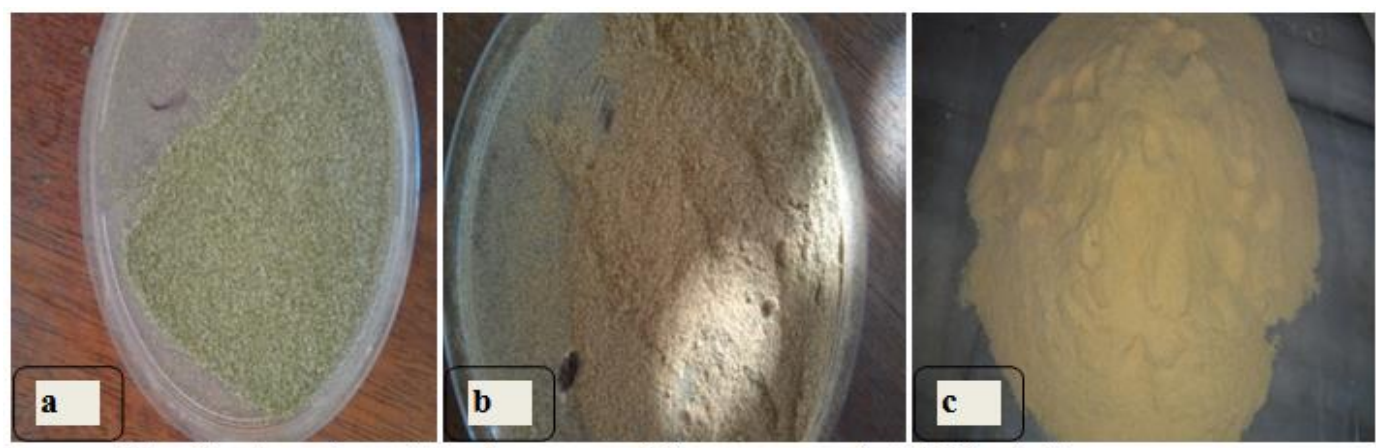

a. = Ulva Lactuca, b. = Grasshopper, c. Microencapsulated WholeEgg

Figure 1. Powdered ingredients. 
feeding the $C$. gariepinus fry with artemia in an intensive system lasts for 14 days (FAO 2015), therefore, this feeding trial lasts for a period of two weeks.

\section{Monitoring Growth (Weight and Length) of Experimental Fish}

The Growth of all experimental fry was monitored on a weekly basis. Weighing of fry was conducted using digital weighing balance while the total length of the fish was measured using a graph paper attached to Petri dish.

\section{Calculation and Statistical Analysis of the Data Economic Analysis}

The cost of the tested ingredients and materials used in hatching the fry during the present research were the only considered source for investment (Table $1 \& 2$ ). Sale Price of fry was obtained by converting the sale price of fingerlings (Size/price $=0.2 \$ / 5000 \mathrm{mg} \mathrm{FAO}$, $2015)$ in relation to the sizes of fry in each treatment. The formulae for economic evaluations were implemented as follows:

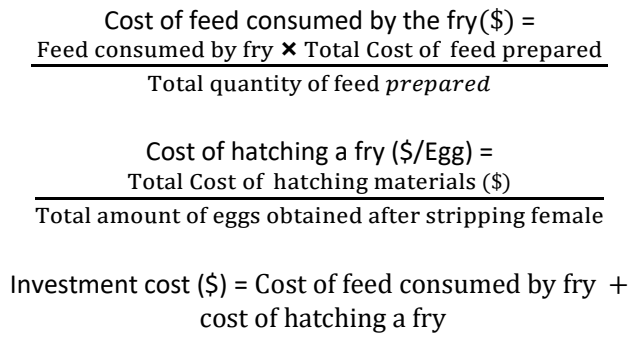

Sale price of Fry $(\$)=\frac{0.2 \$ \times \text { Final weight of fry after feeding trial }(\mathrm{mg})}{5000 \mathrm{mg}}$

Profit index $=\frac{\text { Sale Price of fry after feeding trial }(\$)}{\text { Investment cost }(\$)}$

Net profit $=$ sales price of fry - Investment cost

\section{The Equations Used in Data Analysis}

The following equations were applied to the data obtained after feeding trial:

Weight gain by the fry $(\mathrm{mg})=$ Average final weight of fry - Average initial weight of fry.

Length gain by fry $(\mathrm{mm})=$ Average final length of fry Average initial length of fry.

$$
\begin{gathered}
\text { Specific growth rate }(\% / \text { day })=\frac{\log \mathrm{Wf}-\log \mathrm{Wi}}{\mathrm{T} 1-\mathrm{T} 2} \times 100 \\
\text { Feed conversion ratio }=\frac{\text { Total feed intake }(\mathrm{mg})}{\text { Total weight gain }(\mathrm{mg})} \\
\text { Relative growth rate }(\%)=\frac{\mathrm{Wf}-\mathrm{Wi}}{\mathrm{Wi}} \times 100 \\
\text { Feeding efficiency }(\%)=\frac{\text { Total weight gain }(\mathrm{mg})}{\text { Total feed intake }(\mathrm{mg})} \times 100
\end{gathered}
$$

Where $W_{f}=$ Final body weight of fish at time $T 2$ (day), Wi = initial body weight of fish at time T1 (day).

The results were analyzed using one-way analysis of variance with the aid of sigma stat software Version 3.5. The Fisher LSD test was used to further compare the mean differences.

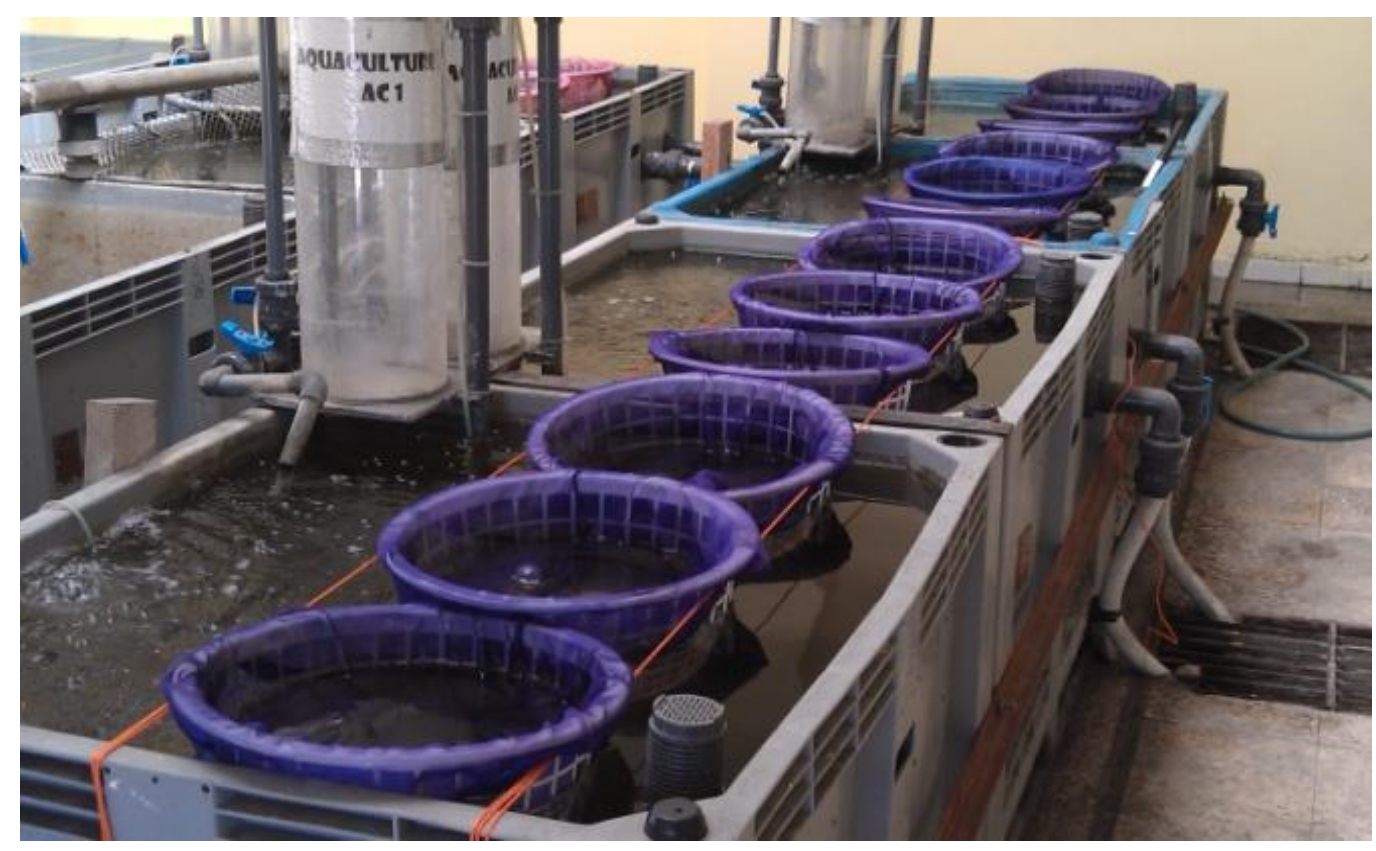

Figure 2. Section view of experimental design. 


\section{Results}

In this study, it was found that Powdered microencapsulated whole egg, grasshopper and $U$. lactuca interacted in a variety of ways to produce viably economic diets for $C$. gariepinus fry production. The powdered diets produced were from single or mixture of ingredients with either low-nutrient-low-cost, lownutrients-high-cost, high-nutrients-low-cost or highnutrient-high-cost (Table $2 \& 3$ ). A summary of variation in growth performance and economic viability of the early stages of $C$. gareipinus fry were presented in Table 4. The initial mean weight and length of the experimental fry were not significantly different $(P>0.05)$.

\section{Growth Performance of the Fry}

During feeding trial with Shell free Artemia as a control, there were significant differences in terms of growth performance among the treatments $(P<0.05$, see Table 4). Growth performance of fry (weight gain = $63.41 \pm 1.3)$ in $T_{6}$ (1:1 mixture of powdered grasshopper and Microencapsulated whole egg) is higher than fry in the control $\left(T_{0}=\right.$ Artemia shell-free, weight gain $=$
49.61 \pm 1.0 ). However, the growth performance of fry in control is higher than the fry of $T_{5}, T_{4}, T_{3}, T_{2}$, and $T_{1}$.

\section{Economic Response of the Fry}

Investment cost was significantly higher in control $T_{0}\left(187.5 \pm 1.3 \times 10^{-5} \$\right)$ than all of the experimental treatments $(\mathrm{P}<0.05)$. $\mathrm{T}_{6}$ recorded high sale price $(260 \pm$ $\left.5.44 \times 10^{-5} \$\right)$, followed by control $\left(204 \pm 4.25 \times 10^{-5} \$\right)$ and $T_{5}\left(165 \pm 3.6 \times 10^{-5} \$\right)$ while the low price was recorded in the remaining treatments $(P<0.05)$. Net profit in $\mathrm{T}_{6}\left(154.4 \pm 5.2 \times 10^{-5} \$\right)$ and $\mathrm{T}_{5}\left(59.5 \pm 3.4 \times 10^{-5} \$\right)$ were higher than control (16.5 $\left.\pm 5.6 \times 10^{-5} \$\right)$. However, Net profit in control not differ significantly with $T_{2}$ (16.9 $\left.\pm 2.5 \times 10^{-5} \$\right)$ and $\mathrm{T}_{4}\left(26.6 \pm 2.7 \times 10^{-5} \$\right)$. Failure in profit was observed in $\mathrm{T}_{1}\left(-14.3 \pm 2.5 \times 10^{-5} \$\right)$ and $\mathrm{T}_{7}(-12.7 \pm$ $\left.1.9 \times 10^{-5} \$\right)$ while low profit in $\mathrm{T}_{3}\left(5.3 \pm 3.5 \times 10^{-5} \$\right)$ $(P<0.05)$ (see Fig. $3 \&$ Table 4$)$. The best profit index observed in $T_{6}(2.5 \pm 0.05)$ and $T_{5}(1.6 \pm 0.03)$ were the indication of prospect in using mixture of powdered feed of these treatments. Though no profit loss was observed in $T_{3}, T_{4}$, and $T_{2}$, their profit index values indicated that the powdered ingredients of these treatments are not feasible as an alternative feed for $C$. gariepinus fry.

Table 1. Cost of materials for hatching

\begin{tabular}{lcc}
\hline Materials for Hatching & Quantity & Cost(\$) \\
\hline Broodstock & 2 & 31.25 \\
Hormone & $1 \mathrm{ml}$ & 2.81 \\
Syringe & $1(10 \mathrm{ml})$ & 0.13 \\
Net & 1 yard & 1.25 \\
Total cost of hatching materials & & 35.44 \\
\hline
\end{tabular}

Table 2. Quantity and cost of feed prepared in each treatment

\begin{tabular}{lcc}
\hline Treatments & Quantity $(\mathrm{mg})$ & Cost $(\$)$ \\
\hline Artemia $\left(\mathrm{T}_{0}\right)$ & 500000 & 28.13 \\
Ulva lactuca $\left(\mathrm{T}_{1}\right)$ & 50000 & 0.38 \\
Grasshopper $\left(\mathrm{T}_{2}\right)$ & 50000 & 0.31 \\
Table egg $\left(\mathrm{T}_{3}\right)$ & 50000 & 0.68 \\
$\mathrm{~T}_{4}\left(\mathrm{~T}_{1}+\mathrm{T}_{2}\right)$ & 100000 & 0.69 \\
$\mathrm{~T}_{5}\left(\mathrm{~T}_{1}+\mathrm{T}_{3}\right)$ & 100000 & 1.06 \\
$\mathrm{~T}_{6}\left(\mathrm{~T}_{2}+\mathrm{T}_{3}\right)$ & 100000 & 0.99 \\
$\mathrm{~T}_{7}\left(\mathrm{~T}_{1}+\mathrm{T}_{2}+\mathrm{T}_{3}\right)$ & 150000 & 1.37 \\
\hline
\end{tabular}

Table 3. Proximate composition of the experimental ingredients

\begin{tabular}{lcccc}
\hline $\begin{array}{l}\text { Parameters } \\
(\%)\end{array}$ & Grasshopper & Microencapsulating whole egg & U. lactuca \\
\hline Crude protein & 13.5 & 16.4 & 1.4 & Artemia shell-free \\
Crude lipid & 10.5 & 39.4 & 9.3 & 9.9 \\
Ash & 8.4 & 4.5 & 9.6 & 5 \\
Moisture & 5.9 & ---- & ---- \\
Fibre & ---- & & 5 & 9 \\
\hline
\end{tabular}




\section{Discussion}

The differences in nutritional compositions and the cost of ingredients have affected the growth performance and economic responses of the fry in all the experimental treatments. As suggested by Uys (1985), C. gariepinus fry requires protein of around 55\%, lipid of $9 \%$ and carbohydrate of $21 \%$. Whether high or low nutrients, the success of fish growth depends largely on the level and quality of the nutrient of the ingredients used (Parker, 2012). The growth of early-stage $C$. gariepinus depends on the essential amino acids, fatty acids of the omega- 3 series (Bell et al, 1986; FAO, 2012), minerals (as calcium, iron) and vitamins especially ascorbic acid (FAO, 2012). However, level of these important nutrients above or below the optimum requirements may cause poor growth performance hence affecting the economic response of the fry.

During this study, low protein and lipid contents to meet the requirement of $C$. gariepinus fry were associated with poor growth performance observed in $\mathrm{T}_{1}$ (Ulva lactuca). While the excess of minerals and lipids is probably associated with poor growth in $T_{7}$ (1:1:1 Mixture of Grasshopper, $U$. lactuca and microencapsulated whole egg). This cause the observed profit lost in $\mathrm{T}_{1}$ and $\mathrm{T}_{7}$.

Despite low growth performance, improvements were observed in $\mathrm{T}_{3}$ (Microencapsulated whole eggs), $\mathrm{T}_{4}$ (1:1 mixture of Ulva lactuca and Grasshopper) and $T_{2}$ (Grasshopper). This is because microencapsulated whole eggs and Grasshopper are rich in lipid which probably mates lipid requirement for C. gariepinus fry

Table 4. Growth performance and economic responses of the fry in different treatments

\begin{tabular}{|c|c|c|c|c|c|c|c|c|}
\hline Parameters & $\mathrm{T}_{0}$ & $\mathrm{~T}_{1}$ & $\mathrm{~T}_{2}$ & $\mathrm{~T}_{3}$ & $\mathrm{~T}_{4}$ & $\mathrm{~T}_{5}$ & $\mathrm{~T}_{6}$ & $\mathrm{~T}_{7}$ \\
\hline Initial weight (mg) & $1.49 \pm 0.03^{a}$ & $1.49 \pm 0.03^{a}$ & $1.49 \pm 0.03^{a}$ & $1.49 \pm 0.03^{a}$ & $1.49 \pm 0.03^{a}$ & $1.49 \pm 0.03^{a}$ & $1.49 \pm 0.03^{a}$ & $1.49 \pm 0.03^{a}$ \\
\hline Initial length (mm) & $6.56 \pm 0.26^{a}$ & $6.56 \pm 0.26^{a}$ & $6.56 \pm 0.26^{\mathrm{a}}$ & $6.56 \pm 0.26^{a}$ & $6.56 \pm 0.26^{a}$ & $6.56 \pm 0.26^{a}$ & $6.56 \pm 0.26^{a}$ & $6.56 \pm 0.26^{a}$ \\
\hline Final weight (mg) & $51.10 \pm 1.1$ & $23.0 \pm 0.55$ & $28.8 \pm 0.67$ & $33.5 \pm 0.73$ & $31.9 \pm 0.73$ & $41.3 \pm 0.90$ & $64.9 \pm 1.36$ & $23.8 \pm 0.55$ \\
\hline Final length (mm) & $17.23 \pm 0.22$ & $16.0 \pm 0.23$ & $16.3 \pm 0.23$ & $16.43 \pm 0.21$ & $15.1 \pm 0.20$ & $16.83 \pm 0.23$ & $18.77 \pm 0.25$ & $12.7 \pm 0.14$ \\
\hline Weight gain (mg) & $49.61 \pm 1.0^{\mathrm{b}}$ & $21.51 \pm 0.5^{f}$ & $27.31 \pm 0.6^{\mathrm{e}}$ & $32.01 \pm 0.7^{d}$ & $30.41 \pm 0.7^{d}$ & $39.81 \pm 0.9^{c}$ & $63.41 \pm 1.3^{\mathrm{a}}$ & $22.31 \pm 0.5^{f}$ \\
\hline Length gain $(\mathrm{mm})$ & $10.67 \pm 0.22$ & $9.44 \pm 0.23$ & $9.74 \pm 0.23$ & $9.87 \pm 0.21$ & $8.54 \pm 0.20$ & $10.27 \pm 0.23$ & $12.21 \pm 0.25$ & $6.14 \pm 0.14$ \\
\hline Relative growth rate (\%) & $3329.31 \pm 71$ & $1443.6 \pm 37$ & $1832.9 \pm 45$ & $2148.3 \pm 49$ & $2040.3 \pm 49$ & $2671.8 \pm 60$ & $4255.7 \pm 91$ & $1497.3 \pm 37$ \\
\hline Specific growth rate (\%) & $10.97 \pm 0.06$ & $8.49 \pm 0.07$ & $9.02 \pm 0.07$ & $9.66 \pm 0.067$ & $9.50 \pm 0.07$ & $10.31 \pm 0.07$ & $11.71 \pm 0.06$ & $8.60 \pm 0.07$ \\
\hline Total food consumed (mg) & $18.29 \pm 0.4$ & $20.48 \pm 0.5$ & $21.89 \pm 0.5$ & $32.52 \pm 0.7$ & $35.1 \pm 0.8$ & $19.51 \pm 0.4$ & $21.18 \pm 0.4$ & $25.41 \pm 0.6$ \\
\hline Food conversion ratio & $0.37 \pm 0.01^{\mathrm{a}}$ & $0.95 \pm 0.03^{d}$ & $0.8 \pm 0.01^{c}$ & $1.02 \pm 0.03^{e}$ & $1.15 \pm 0.01^{f}$ & $0.49 \pm 0.005^{b}$ & $0.33 \pm 0.003^{a}$ & $1.14 \pm 0.01^{f}$ \\
\hline Feeding efficiency (\%) & $270.3 \pm 9.1^{b}$ & $105.3 \pm 4.0^{\mathrm{e}}$ & $125 \pm 1.3^{d}$ & $98 \pm 3.4^{\mathrm{e}}$ & $86.96 \pm 0.8^{e}$ & $204.1 \pm 2.02^{c}$ & $303.3 \pm 3.01^{a}$ & $87.72 \pm 0.85$ \\
\hline Hatching cost $\left(\times 10^{-5} \$\right)$ & $84.5 \pm 0.0$ & $84.5 \pm 0.0$ & $84.5 \pm 0.0$ & $84.5 \pm 0.0$ & $84.5 \pm 0.0$ & $84.5 \pm 0.0$ & $84.5 \pm 0.0$ & $84.5 \pm 0.0$ \\
\hline Cost of food consumed $\left(\times 10^{-5} \$\right)$ & $103 \pm 1.3^{\mathrm{a}}$ & $21.8 \pm 0.31^{c}$ & $13.6 \pm 0.18^{e}$ & $44.2 \pm 0.55^{b}$ & $16.9 \pm 0.22^{d}$ & $21 \pm 0.25^{c}$ & $21.1 \pm 0.23^{c}$ & $23.2 \pm 0.32^{c}$ \\
\hline Investments' cost $\left(\times 10^{-5} \$\right)$ & $187.5 \pm 1.3^{\mathrm{a}}$ & $106.3 \pm 0.31^{c}$ & $98.1 \pm 0.18^{e}$ & $128.7 \pm 0.55^{b}$ & $101.4 \pm 0.22^{d}$ & $105 \pm 0.25^{c}$ & $105.1 \pm 0.23^{c}$ & $107.7 \pm 0.32^{c}$ \\
\hline Sale $\left(\times 10^{-5} \$\right)$ & $204 \pm 4.25^{b}$ & $92 \pm 2.22^{f}$ & $115 \pm 2.67 \mathrm{e}$ & $134 \pm 2.9^{d}$ & $128 \pm 2.92^{\mathrm{d}}$ & $165 \pm 3.6^{c}$ & $260 \pm 5.44^{\mathrm{a}}$ & $95 \pm 2.21^{f}$ \\
\hline Profit index & $1.1 \pm 0.03^{\mathrm{d}}$ & $0.87 \pm 0.02^{\mathrm{e}}$ & $1.17 \pm 0.03^{d}$ & $1.04 \pm 0.03^{d}$ & $1.3 \pm 0.03^{c}$ & $1.6 \pm 0.03^{b}$ & $2.5 \pm 0.05^{\mathrm{a}}$ & $0.9 \pm 0.02^{\mathrm{e}}$ \\
\hline Net Profit $\left(\times 10^{-5} \$\right)$ & $16.5 \pm 5.6^{c}$ & $-14.3 \pm 2.5^{e}$ & $16.9 \pm 2.5^{c}$ & $5.3 \pm 3.5^{d}$ & $26.6 \pm 2.7^{c}$ & $59.5 \pm 3.4^{b}$ & $154.4 \pm 5.2^{\mathrm{a}}$ & $-12.7 \pm 1.9^{e}$ \\
\hline Feed cost $(\%)$ & $54.9 \pm 0.3$ & $20.51 \pm 0.2$ & $13.86 \pm 0.2$ & $34.34 \pm 0.3$ & $16.67 \pm 0.2$ & $19.90 \pm 0.2$ & $19.98 \pm 0.2$ & $21.54 \pm 0.2$ \\
\hline
\end{tabular}

* The same superscript on raw indicated no significant differences

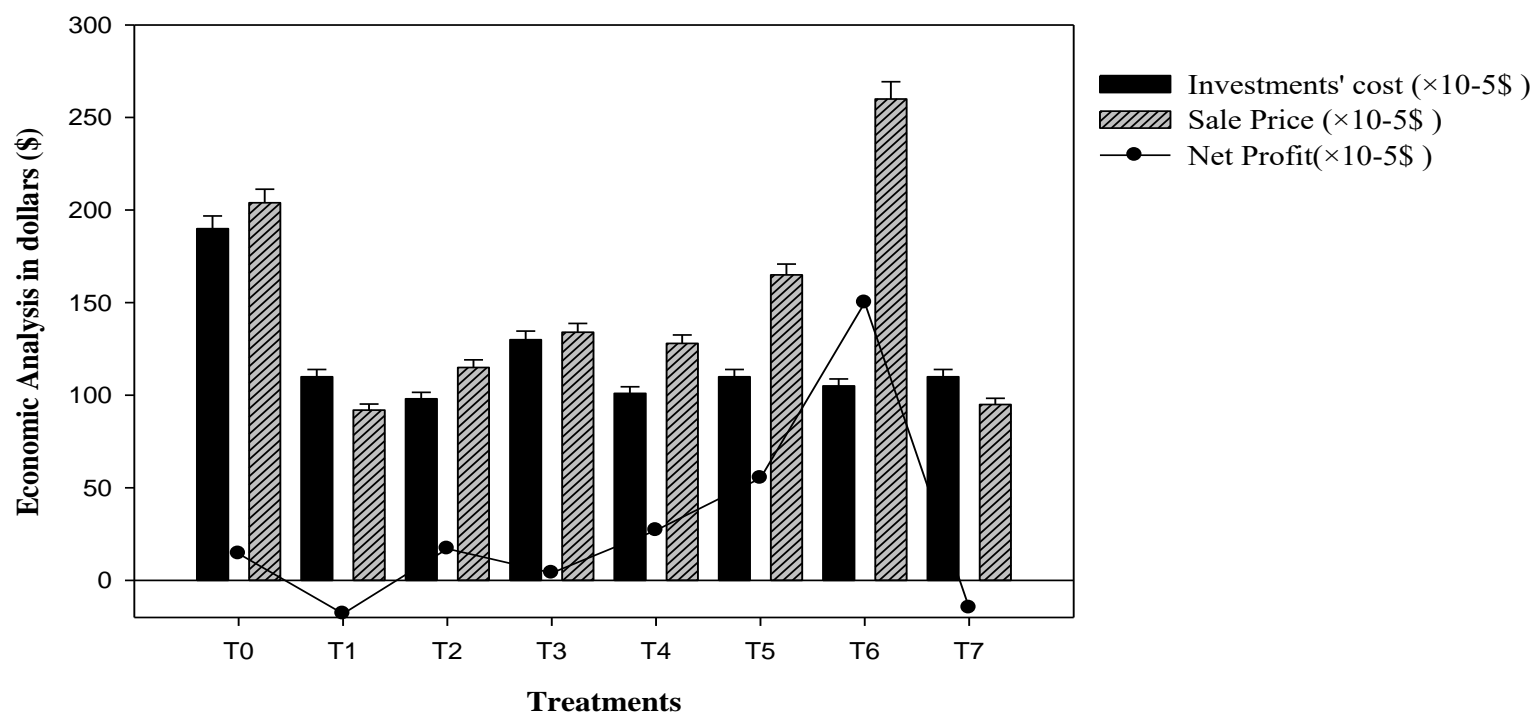

Figure 3. Economic response of the Fry. 
(Uys, 1987). However, Growth in $\mathrm{T}_{\mathbf{3}}$ (Microencapsulated whole eggs) is expected to be higher than the current performance of our study. The low growth performance observed might be due to the clumping of powdered microencapsulated whole egg particles exceeding the mouth size of the fry some minutes after we feed the fry. Microencapsulated Whole eggs lack some vitamins (e.g. Ascorbic acid) and sufficient minerals like calcium and iron (Chow, 1986; FAO, 2012). Also, Powdered microencapsulated whole egg of our study has excess dietary lipid and excess dietary lipid is reported to reduced nutrient utilization, resulting in low growth performance of Gilthead Seabream Sparus aurata (Emre et al., 2013). Therefore, we attributed the improved growth performance in $T_{6}$ (1:1 mixture of Grasshopper and Microencapsulated whole eggs), and $T_{5}$ (1:1 mixture of $U$. lactuca and Microencapsulated whole eggs) to be associated with high lipid content of Microencapsulated whole egg as well as the minerals, vitamins, essential amino acid and essential fatty acid content of grasshopper (Adeyeye, 2005; Adeyeye, 2011; Hui et al., 2013) and U. lactuca (Ortiz et al., 2006; GarciCasel et al., 2007; Kumar and Khaldar, 2007; RohaniGhadikolaei et al., 2012) that possibly enriched the powdered microencapsulated whole eggs. Vitamin C (ascorbic acid) promotes lipid metabolism, thus reduced carcass lipid and increases protein levels (Ji et al., 2003). Minerals improve growth performance, electron transfer, regulation of acid-base equilibrium, and osmoregulation for fish normal life processes (Parker, 2012). However, growth performance in $T_{6}$ is higher than $\mathrm{T}_{5}$ which could be due to the high protein, lipid and 1:1 (50: 50\%) mixture of Mictoencapsulated whole egg and grasshopper of feed in $T_{6}$. Alegbeleye et al., (2011) shows that adding $25 \%$ Zonocerus variegates grasshopper meal enhanced growth performance of $C$. gariepinus. On the other hand, mixture of $U$. lactuca and "Microencapsulated whole egg" in the ratio of 1:1 (50:50\%) in $\mathrm{T}_{5}$ probably slows the growth performance of fry in this group when compared with growth of $\mathrm{T}_{6}$. Ergun et al. (2008) find that low-level inclusion (5\%) of U. lactuca improved growth performance in Tilapia fed high-lipid diets. Eltawil, (2010) indicates that adding 15\% level of $U$. lactuca in the diet of Red Tilapia resulted in increased weight and specific growth rate. It was further suggested that low dietary incorporation of Ulva in the diets of Nile Tilapia improved growth performance, feed utilization, physiological activity, disease resistance, carcass quality, and reduced stress response (Mustafa and Nakagawa 1995; Waseef et al., 2005; Valente et al., 2006). Therefore, C. gariepinus as omnivorous fish should have low level of inclusion of $U$. lactuca. Although only growth performance in $T_{6}$ is higher than control, improvement in growth performance and high net profit made us suggest the consideration of $T_{5}$ to be promising too.

Unlike control ( $T_{0}=$ Artemia shell free), low investment cost and high profit were found in $T_{6}$ and $T_{5}$.
However considering the high protein and lipid content of Artemia, control was expected to have high growth performance to compensate for the high investment cost as to have a high profit. Low growth in control could be due to the deficiency of some essential fatty acid in Artemia naupuli (Olurin et al., 2014) and lack of essential fatty acids reduces growth and nutrient utilization (Parker, 2012). Artemia naupuli enriched with cod liver oil improves growth and survival of $C$. gariepinus larvae (Olurin et al., 2014). Enriching Artemia with vitamin C and unsaturated fatty acid enhanced growth performance of Trout (Akbary et al., 2011), Acipenser persicus and Huso huso (Noori et al., 2011) and Sturgeon (Hafezieh et al., 2009) larvae.

\section{Conclusion}

In the aim of reducing the cost of feeding while maintaining the best growth and enhancing the profit in Clarias gariepinus seed production, the present study show that, the cost was reduced from $54.9 \%$ in the control (Artemia shell free) to $19.98 \%$ and $19.90 \%$ in $T_{6}$ (1:1 mixture of grasshopper and microencapsulated whole egg) and $T_{5}$ (1:1 mixture of $U$. lactuca and Microencapsulated whole egg) respectively. Our study indicated that the experimental ingredients of $T_{6}$ and $T_{5}$ can be utilized as alternative feed sources for $C$. gariepinus fry and can be affordable for fish farmers with great benefit. Therefore, more should be explored on benefit of combination of ingredients of feed in $T_{6}$ and $\mathrm{T}_{5}$.

\section{References}

Adeyeye, E. (2005). Amino acid composition of variegated grasshopper, Zonocerus variegatus. Tropical Science, 45(4), 141-143. https://doi.org/10.1002/ts.9

Adeyeye, E. (2011). Fatty acid composition of Zonocerus variegatus, Macrotermes bellicosus and Anacardium occidentale kernel. International Journal of Pharma and Bio Sciences, 2(1), 135-144.

Akbary, P., A, Hosseini S and Imanpoor, M. R. (2011). Enrichment of Artemia naupulii with essential fatty acids and vitamin C: effect on rainbow trout (Oncorhynchus mykiss) larvae performance. Iranian Journal of Fisheries Sciences, 10(4), 557 - 569.

Alegbeleye, W. O., Sam, O. O basa, Olude, O. O., Otubu, K., \& Jimoh, W. (2011). Preliminary evaluation of the nutritive value of the variegated grasshopper (Zonocerus variegatus L.) for African catfish Clarias gariepinus (Burchell. 1822) fingerlings. Aquaculture Research, 43(3), 1-9. https://doi.org/10.1111/j.1365-2109.2011.02844.x

APHA/AWWA/WPCF /ic Health.American Association water work Association. Water pollution Control federation). (1995). Standard Method for the examination of water and wastewater. Washington DC, America: Public health association.

Association of Official Analytical chemist. (1990). Official Method of Analysis Association of Official Analytical 
chemist. Arlington, Virginia: Helrich K. Published https://doi.org/10.1016/0165-9936(90)87098-7

Bell, M.V., Henderson, R.J. and Sargent J.R. (1986). The role of polyunsaturated fatty acids in fish. Comp.Biochem. Physiol. B Biochem. Mol. Biol, 83(4), 711-719. https://doi.org/10.1016/0305-0491(86)90135-5

Blásquez, J.R., Moreno, José, M.P., Camacho, V and Hugo, M. (2012). Could Grasshoppers Be a Nutritive Meal? Food and Nutrition Sciences, 164-175. https://doi.org/10.4236/fns.2012.32025

Chow, K.W (1980). Microencapsulated egg diets for fish larvae. In FAO, Fish Technology (pp. 355-361). Fisheries and Aquaculture Departments.

De Graaf, G and Johannas J. (1996). A Handbook on the artificial reproduction and pond rearing of the African catfish Clarias gariepinus in sub-Saharan Africa. Rome: FAO, fisheries technical paper362.

El-Tawil, N. E. (2010). Effects of Green Seaweeds (Ulva sp.) as Feed Supplements in Red Tilapia (Oreochromis Sp.) Diet on Growth Performance, Feed Utilization And Body Composition. Journal of the Arabian Aquaculture Society, 5(2), 179-194.

Emre, Y., Ergun, S., Kurtoglu, A., Guroy, B., and Guroy, D. (2013). Effect of Ulva meal on Growth Performance of Gilthead Seabream (Sparus aurata) at Different Level of Dietary Lipid. Turkish Jornal of fisheries and aquatic sciences, $13(1), \quad 841 \quad-\quad 846$ https://doi.org/10.4194/1303-2712-v13_5_08

Ergun, S., Soyuturk, M., Guroy, B., and Guroy, D. (2008). Influence of Ulva meal on growth, feed utilization, and body composition of juvenile Nile tilapia(Oreochromis niloticus) at two levels of dietary lipid. Aquacult Int. https://doi.org/10.1007/s10499-008-9207-5

FAO. (2015). Cultured Aquatic Species Information Programme: Clarias gariepinus (Burchell, 1822). Retrieved from Fisheries and Aquaculture Department:

http://www.fao.org/fishery/culturedspecies/Clarias_ga riepinus/en

Garci'a-Casal MN., Pereia, AC., Leets, I., Ramirez, J and Quiroga, MF. (2007). High iron content and bioavailability in humans from four species of marine algae. J Nutr, 137, 2691-2695. https://doi.org/10.1093/jn/137.12.2691

Gietma, B. (2003). Fish Farming in Tropical Fresh Water. Wageningen, Netherland: Agromesia.

Hafezeih, M., Kamarudin, M. S., Saad, C. R., Abdsattar, M. K., Agh, N., and Hosseinpour, H. (2009). Effect of Enriched Artemia urmiana on Growth, Survival, and Composition of Larval Persian Sturgeon. Turkish Journal of Fisheries and Aquatic Sciences, 9, 201 - 207. https://doi.org/10.4194/trjfas.2009.0212

Huis, A. v., Itterbeeck, J. V., Klunder, H., Mertens, E., Halloran, A., Muir, G., \& Vantomme, P. (2013). Edible insect future prospective for food and feed security. Rome: FAO 171.

Ibrahim, M.S.A., Mona, H.A., and Muhammad., A. (2008). Zooplankton as live food for fry and fingerlings of Nile Tilapia (Oreochromis niloticies) and catfish Clarias gariepinus in concrete ponds. International Symposium on Tilapia in Aquaculture. Abbasa, Shrkia, Egypt.

Ji, H., Om, A., Umino, T., and Nakagawa, A. (2003). Effect of dietary ascorbate fortification on lipolysis activity of Juvenile black sea bream Acanthopagyrus schlegeii. Fisheries Science, 69(1), 66-73. https://doi.org/10.1046/j.1444-2906.2003.00589.x
Kumar V.V and Kaldhran, P. (2007). Amino acids in the seaweeds as an alternate source of protein for animal feed. J. Marine Biology.Ass India, 49(1), 35-40.

Marimuthu K., and Haniffa M.A., Aminurrahman, M. (2009). Spawning performance of native threatened spotted snakehead fish, Channa punctatus Actinopterygii: Channidae: perciformea) induce with ovatides. Acta Ichthyol. Piscat, 39(1), 1-5. https://doi.org/10.3750/AIP2009.39.1.01

Moustafa, Y. T.A., and Saeed, S. M. (2014). Nutritional evaluation of green macroalgae, Ulva $s p$. and related water nutrients in the Southern Mediterranean Sea coast, Alexandria shore, Egypt. Egypt. Acad. J. Biolog. Sci., 5(1), $\quad 1 \quad-19$ https://doi.org/10.21608/eajbsh.2014.16825

Mustafa MG, Nakagawa. H. (1995). A review: dietary benefits of algae as an additive in fish feed. Isr J Aquacult-Bamid, 47, 155-162.

Noori, F., G. A, Takami., M. V, Speybroeck., G. V, Stappen., A .R, Shiri-Harzevili., and P, Sorgeloos(2011). Feeding Acipenser persicus and Huso huso larvae with Artemia urmiana nauplii enriched with highly unsaturated fatty acids and vitamin C: effect on growth, survival and fatty acid profile. Journal of Applied Ichthyology, 27(2), 781 786. https://doi.org/10.1111/j.1439-0426.2010.01647.x

Ojewola G., Annuli. (2005). Nutritive and Economic value of Danish fish meal, crayfish dust meal and shrimp meal inclusion in broiler diets. Afr J. Biotech, 5(4), 390-394. https://doi.org/10.3923/ijps.2006.390.394

Ojewola, G.S., and Udom, S.F. (2003). Effect of inclusion of grasshopper meal on performance, Nutrient utilization, and organ of Broiler chicken. J. Sustain. Agri.

Environ., 5, 19-25.

Olurin, B. K., and Layeni, M. A. (2014, December Friday). world Aquaculture society. Retrieved from https://www.was.org/meetings/ShowAbstract.aspx?ld= 33513

Ortiz, J., Romero, N., Robert, P., and Araya, J. L . (2006). Dietary fiber, amino acid, fatty acid and tocopherol contents of the edible seaweeds Ulva lactuca and Durvillaeaantarctica. Food Chemistry, 99, 98-104. https://doi.org/10.1016/j.foodchem.2005.07.027

Ovie, S.I, and Ovie, S.O (2002). Fish-larval rearing: the effect of pure/mixed zooplankton and artificial diet on the growth \& survival of Clarias anguilaris (Linnaeus, 1758) larvae. Journal of Aquatic Science, 17(1), 69-73. https://doi.org/10.4314/jas.v17i1.19915

Parker, R. (2012). Aquaculture Science. USA: Cengage learning. Rohani-Ghadikolaei, K., Abdulalian, E., and Ng, Wing-Keong. (2012). Evaluation of the proximate, fatty acid and mineral composition of representative green, brown and red seaweeds from the Persian Gulf of Iran as potential food and feed resources. J Food Sci Technol, 49(6), 774780. https://doi.org/10.1007/s13197-010-0220-0

Rumsey, G.L (1980). Novel Diets For Aquaculture. In FAO, Fish feed Technology. Washington: Fisheries and Aquaculture Department.

Sani, I., Haruna, M., Abdulhamid, A., Warra, A., Bello, F., \& Fakai, I. (2014). Assessment of Nutritional Quality and Mineral Composition of Dried Edible Zonocerus variegatus (Grasshopper). Research \& Reviews: Journal of Food and Dairy Technology.

Uys, W., and Hecht, T. (1985). Evaluation and preparation of an optimal dry feed for the primary nursing of Clarias gariepinus larvae (Pisces: Clariidae). ASWquaculture, 47, 
173-183. https://doi.org/10.1016/00448486(85)90063-8

Valente, LMP., Gouveia, A., Rema, P., Matos, J., and Gomes, E. P. (2006). Evaluation of three seaweeds Gracilaria bursapastoris, Ulva rigida and Gracilaria cornea as dietary ingredients in European seabass Dicentrarchus labrax juveniles. Aquaculture, 252, 85-91. https://doi.org/10.1016/j.aquaculture.2005.11.052

Wassef, EA., El-Sayed, AFM., Kandeel, ..., and Sakr, E.M. (2005). Evaluation of Pterocla dia and Ulva meals as additives to gilthead seabream Sparus aurata diets. Egypt J Aquat Res, 31, 321-332. 